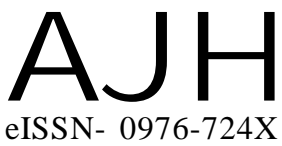

Received : 14.03.2016

Revised : 07.04.2016

Accepted : 20.04.2016
Members of the Research Forum

Associated Authors:

${ }^{1}$ Ratnai College of Agriculture, AKLUJ (M.S.) INDIA
Author for correspondence : SHAILENDRA R. MANE

Ratnai College of Agriculture, AKLUJ (M.S.) INDIA

Email : shailenrmane@gmail.com
THEASIAN JOURNALOF HORTICULTURE

Volume 11 | Issue 1 | June, 2016 | 30-35

Visit us -www.researchjournal.co.in

\title{
Physiological changes induced by maturity indices, post-harvest treatments and storage temperature in mango cv. KESAR
}

\section{SHAILENDRA R. MANE, Y.T. JADHAV ${ }^{1}$ AND D.P. BARKADE ${ }^{1}$}

ABSTRACT : Fruit volume, Physiological weight in loss of Kesar' mango gradually increase till the end of shelf-life and exhibited inversely proportional relationship with specific gravity of fruit while the maximum physiological loss in weight in immature fruits with sp.gr. less than 1.00 as compared sp.gr. more than 1.00. Whereas, maximum organoleptic evaluation reported in sp.gr. more than 1.02. Dip treatment of harvested fruits in bavistin $500 \mathrm{ppm}$ for $5 \mathrm{~min}$. had been found to be useful for enhancing the flavour and consumer acceptability. Beneficial effect on minimizing physiological weight loss, maximum fruit volume and firmness in wax coating $(6 \%)$ followed by bavistin $500 \mathrm{ppm}$ for $5 \mathrm{~min}$. Delay in PLW, maximum fruit volume and firmness with lower organoleptic score were registered at $15^{\circ} \mathrm{C}$ of storage temperature with 85 per cent $\mathrm{RH}$.

KEY WORDS : Kesar, Maturity indices, PLW, Waxing, Fruit volume

HOW TO CITE THIS ARTICLE : Mane, Shailendra R., Jadhav, Y.T. and Barkade, D.P. (2016). Physiological changes induced by maturity indices, post-harvest treatments and storage temperature in mango cv. KESAR. Asian J. Hort., 11(1) : 30-35, DOI : 10.15740/HAS/TAJH/11.1/30-35. 